\title{
TATRZAŃSKI PARK NARODOWY - KONFLIKT OCHRONY PRZYRODY I TURYSTYKI ${ }^{1}$
}

Obszar chroniony, który został zaprezentowany w niniejszej pracy, to Tatrzański Park Narodowy (TPN) - piąty co do wielkości park narodowy w Polsce. Został utworzony w 1954 r. i do dziś pozostaje jednym z najchętniej odwiedzanych polskich parków narodowych. Położony jest w południowej części kraju - w Tatrach, które są najwyższym pasmem górskim w Polsce, a co za tym idzie - znajduje się tutaj również najwyższy polski szczyt - Rysy. Do parku najczęściej sprowadza podróżnych chęć wypoczynku, na co wpływa fakt, że w pobliżu znajduje się Zakopane, stanowiące zaplecze turystyczne Tatr.

Na początek warto przybliżyć zagadnienie dotyczące obciążeń parku ruchem turystycznym, omówione w książce Krzana (2006) pt. Tatrzański Park Narodowy na tle innych górskich terenów chronionych. Z publikacji wynika, że obciążenia te należy wiązać z dobrą dostępnością komunikacyjną obrzeża Tatr oraz z bogatą bazą noclegową znajdującą się w bardzo zurbanizowanej strefie Podtatrza. W pracy zwrócono też uwagę na problematykę dotyczącą zarządzania ruchem turystycznym na tym terenie, a także na sposoby przeciwdziałania synantropizacji fauny. Poruszono również kwestię polityki zagospodarowania przestrzennego tego obszaru i zapobiegania izolowania Tatr od najbliższych cennych przyrodniczo terenów

\footnotetext{
1 Praca jest efektem wykonania przez autorkę zadania, zatytułowanego Turystyka na obszarach chronionych w świetle własnych doświadczeń oraz wiedzy popularnej i naukowej, podczas zajęć dydaktycznych o nazwie turystyczne i rekreacyjne użytkowanie obszarów chronionych, znajdujących się w programie pierwszego roku studiów licencjackich na kierunku turystyka i rekreacja na Uniwersytecie Łódzkim. Więcej na ten temat napisał Piotr Miazek w swojej notatce naukowej pt. Turystyka na obszarach chronionych w Polsce w niniejszym tomie monografii.
} 
Podtatrza. Stwierdzono wprawdzie, że masyw tatrzański zachował jeszcze spójność ekologiczną z Górami Choczańskimi, Magurą Orawską i Magurą Spiską, ale przy obecnych uwarunkowaniach prawnych odnoszących się do zagospodarowania przestrzennego ratowanie łączności Tatr z Orawą i Spiszem może być realizowane poprzez ustanowienie otuliny parku narodowego. Takie działanie stanowi realną szansę kontroli obszarów przyległych do TPN i daje możliwość wyłączenia obszaru otuliny z obwodów łowieckich. Oceniono, że otulina parku np. w gminie Poronin ma olbrzymie znaczenie dla powstrzymania tendencji zabudowywania strefy przyległej do TPN, choć we wsi Małe Ciche obserwuje się silną urbanizację i powstawanie ośrodków narciarskich.

W cytowanej publikacji podkreśla się również, że problem konfliktu ochrony przyrody i udostępniania turystom obszaru TPN wiąże się z jego dostępnością komunikacyjną. Do wylotów dolin można łatwo się dostać dzięki transportowi samochodowemu, a duże parkingi, mające istotny wpływ na wielkość ruchu wejściowego, znajdują się na Siwej Polanie i Palenicy Białczańskiej. W książce stawiane jest pytanie o możliwość nadzorowania ruchu wejściowego na teren parku, choć stosowanie w praktyce regulacji liczby turystów jest wątpliwe. Oznaczałoby to bowiem zamykanie dolin przy stwierdzeniu przekroczenia przyjętej maksymalnej liczby osób, które weszły w kontrolowanym miejscu.

W publikacji postawione było także inne pytanie: Czy należy dążyć do równomiernego rozkładu ruchu turystycznego? Zdaniem autora niekoniecznie. Nierównomierny rozkład turystów mogą wykorzystywać zwierzęta, zwłaszcza gatunki unikające kontaktów z człowiekiem, które wybierają ostoje bez ludzi.

W tym kontekście podkreśla się też, że nadmierny ruch turystyczny wiąże się z ryzykiem kontaktów turystów ze zwierzętami. Najpoważniejszym problemem jest łatwość oswajania się niektórych gatunków z obecnością człowieka. Zwierzęta mają dostęp do porzuconych przez turystów resztek jedzenia i śmieci (notabene najbardziej podatny na synantropizację jest niedźwiedź). Najważniejszym elementem przeciwdziałania temu zjawisku jest stosowanie coraz nowocześniejszych metod monitoringu.

Jako najlepszy sposób na ochronę obszaru parku przed nadmiernym obciążeniem turystycznym wskazuje się utrzymanie utrudnień w dostępie do jego wnętrza. Zaznaczono, że nie może być zgody na budowanie nowych linii kolejowych, tworzenie kolejnych parkingów oraz ich powiększanie. Jedyne ułatwienia powinny dotyczyć działań zmierzających do zastępowania komunikacji indywidualnej transportem zbiorowym. Szansą 
na odciążenie TPN jest tworzenie atrakcyjnej infrastruktury turystycznej czy rekreacyjnej na przedpolu Tatr.

Nadmierna liczba osób przemieszczających się przez tereny TPN może być zniwelowana poprzez otwarcie nowych przejść granicznych i przepływ turystów na stronę słowacką. Nie oznaczałoby to jednak swobodnego przepływu osób w każdym miejscu granicy państwowej w Tatrach. Nadal obowiązywałyby zasady ochrony przyrody i zarządzenia dotyczące ruchu turystycznego określone dla polskiej i słowackiej części TPN. W obu parkach fundamentalną zasadą jest poruszanie się wyłącznie po znakowanych szlakach turystycznych. Przekraczanie granicy państwowej będzie możliwe tylko tam, gdzie stykają się na niej szlaki turystyczne polskie i słowackie.

Kolejną publikacją pozwalającą zapoznać się z tematyką ochrony przyrody w Tatrzańskim Parku Narodowym była monografia pokonferencyjna pod redakcją Chrobaka i Zwijacz-Kozicy (2015) zatytułowana Przyroda Tatrzańskiego Parku Narodowego a człowiek. W książce zawarto m.in. zagadnienia związane $\mathrm{z}$ ruchem turystycznym na terenie parku, poruszone na $\mathrm{V}$ konferencji o wymienionym tytule, zorganizowanej w Zakopanem w dniach 24-26 września 2015 r. W opracowaniu dotyczącym atmosfery ziemskiej stwierdzono, że działalność człowieka wpływa na jej skład na wiele różnych sposobów. Jedną z konsekwencji tej działalności jest znaczący wzrost stężenia niektórych gazów cieplarnianych w ciągu ostatnich 150 lat. Dotyczy to dwutlenku węgla, metanu czy podtlenku azotu, które prowadzą do dodatkowego ogrzewania powierzchni Ziemi. Podsumowano wyniki wieloletnich, systematycznych pomiarów stężeń gazów, które przyczyniają się do powstania efektu cieplarnianego, dokonywanych w KASLAB ${ }^{2}$ na szczycie Kasprowego Wierchu w Tatrach. Wykonywany tam monitoring obejmuje wszystkie podstawowe związki mające wpływ na efekt cieplarniany $\left(\mathrm{CO}_{2}, \mathrm{CH}_{4}, \mathrm{~N}_{2} \mathrm{O}, \mathrm{SF}_{6}\right)$. Rejon Polski południowej, gdzie prowadzony jest monitoring gazów cieplarnianych, charakteryzuje się wysokim stopniem urbanizacji w porównaniu z pozostałymi częściami kraju. W wieloletnim zapisie zmian stężenia gazów śladowych można jednak zaobserwować okresowe wpływy emisji lokalnej na wyniki prowadzonych tam pomiarów, np. działanie silnej emisji antropogenicznej $\mathrm{z}$ terenu Zakopanego. W zapisie pomiarowym z Kasprowego Wierchu jest zauważalne również negatywne oddziaływanie Górnośląskiego Okręgu

2 KASLAB to nazwa laboratorium mieszczącego się w budynku należącym do Instytutu Meteorologii i Gospodarki Wodnej Państwowego Instytutu Badawczego, zlokalizowanego na szczycie Kasprowego Wierchu. 
Przemysłowego (GOP). Tym samym stan atmosfery w TPN systematycznie ulega pogorszeniu.

Walory środowiska przyrodniczego Tatr sprawiają, że góry te należą do najczęściej odwiedzanych obszarów w Polsce. W latach 2009-2012 każdego roku sprzedano ponad 3 mln biletów wstępu do TPN. Wynika z tego, że ze szlaków turystycznych korzysta od 10 do 100 razy więcej użytkowników niż w czasie ich wytyczania, czyli jeszcze przed założeniem TPN (Chrobak, Zwijacz-Kozica, 2015). W wyniku działania antropogenicznych i naturalnych procesów morfogenetycznych nie tylko ulega zniszczeniu pokrywa glebowa i szata roślinna, ale także zachodzą zmiany w rzeźbie powierzchni zarówno w obrębie samych szlaków, jak i w strefach położonych wzdłuż nich.

Na degradacje przyrody w TPN oprócz liczby turystów wpływają również formy turystyki przez nich uprawiane. Tatrzański Park Narodowy to jedyny obszar w Polsce, na którym możliwe jest trenowanie wszystkich rodzajów wspinaczki - od tradycyjnej wspinaczki górskiej po sportową skałkową i bouldering. W literaturze określono wpływ poszczególnych rodzajów wspinaczki na rzeźbę terenu, szatę roślinną i świat zwierzęcy oraz zaproponowano różne ograniczenia dla turystów. Na przykład bariery przestrzenne polegają na wyłączeniu (zamknięciu) pewnych rejonów z uprawiania wspinaczki. W TPN ograniczenia takie dotyczą całego obszaru Tatr Zachodnich i większości rejonów wspinaczkowych w Tatrach reglowych (poza skałką u wylotu Doliny Lejowej i skałką w żlebie Jaroniec) (Chrobak, Zwijacz-Kozica, 2015).

Aby chronić przyrodę TPN przed uciążliwościami nadmiernego ruchu turystycznego, stosuje się również ograniczenia temporalne, polegające na czasowym zamknięciu rejonów wspinaczkowych lub ich fragmentów w celu ochrony lęgów ptaków i zimowisk nietoperzy. Wśród najczęściej wprowadzanych restrykcji jakościowych w udostępnianiu obszarów chronionych do wspinaczki są zakazy odnoszące się do uprawiania jej poszczególnych rodzajów, np. związane z instalacją punktów asekuracyjnych (najczęściej tzw. ringów i spitów osadzanych na stałe, ale także haków szczelinowych lub śrub) czy używania magnezji. Do tej grupy ograniczeń zaliczane są też wytyczne w zakresie korzystania $\mathrm{z}$ radiotelefonów podczas wspinaczki oraz konieczności znoszenia z gór różnych odpadów, także fekaliów (Chrobak, Zwijacz-Kozica, 2015).

Wprowadzane restrykcje ilościowe polegają z kolei na określeniu maksymalnej liczby osób mogących przebywać w danym miejscu. Zgodnie z sugestiami Chrobak i Zwijacz-Kozicy (2015) najwłaściwsze byłoby 
ustalenie tzw. chłonności ekologicznej, czyli możliwości takiego obciążenia wybranego obszaru określoną liczbą turystów, jakie zapewni optymalne warunki wypoczynku i nie spowoduje zachwiania równowagi biocenotycznej systemu. Ustala się również pojemność wspinaczkową, czyli maksymalną liczbę osób uprawiających wspinaczkę jednocześnie w określonym rejonie, korzystających z istniejącej infrastruktury bez obniżania poziomu bezpieczeństwa i komfortu uprawiania wspinaczki (Chrobak, Zwijacz-Kozica, 2015).

W przypadku terenów proponowanych do udostępnienia wyłącznie amatorom wspinaczki skałkowej letniej $w$ Tatrach reglowych wprowadzono następujące ograniczenia jakościowe, mające na celu ochronę rzeźby ścian skalnych i roślinności: dostęp do dróg wspinaczkowych wyłącznie od dołu, instalacja stanowisk zjazdowych poniżej krawędzi ściany, zabezpieczenie podnóża ścian skalnych przed erozją, zakaz modyfikacji rzeźby w obrębie ścian skalnych (kucie i betonowanie chwytów), zakaz uprawiania drytoolingu ${ }^{3}$. W razie stwierdzenia obecności gniazd ptaków w obrębie ścian skalnych zaleca się wprowadzenie dodatkowo ograniczeń czasowych w dostępie do rejonów wspinaczkowych (Chrobak, Zwijacz-Kozica, 2015).

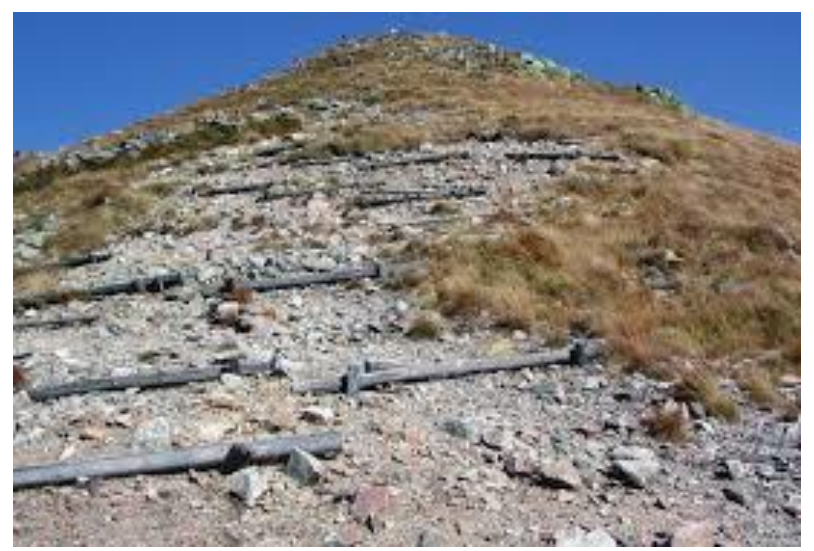

Fot. 1. Przykład zniszczeń oraz regeneracji pokrywy glebowej na stokach Kasprowego Wierchu

Źródło: Gleby TPN

3 Drytooling - rodzaj wspinaczki zimowej z wykorzystaniem sprzętu typowego dla wspinaczki lodowej (takiego jak np. czekany i raki) na nieoblodzonych drogach skalnych. 
Problemem na terenach górskich jest wydeptywanie szaty roślinnej. W krótkim przedziale czasowym, tj. od kilku miesięcy do kilku lat, obserwuje się zmniejszenie procentowego udziału pokrycia przez roślinność powierzchni wydeptywanej przez turystów, a także spadku liczebności gatunków flory oraz ich zdolności reprodukcyjnych. Dochodzi do erozji gleby, a w konsekwencji zmiany struktury roślinnej zbiorowisk. Gdy wydeptywanie przekroczy próg zdolności regeneracyjnych roślin, pokrywa roślinna zostaje całkowicie zdarta, co znacząco intensyfikuje procesy erozyjne (Chrobak, Zwijacz-Kozica, 2015). Fot. 1 przedstawia skalę zniszczenia pokrywy glebowej wraz z próbą jej regeneracji na stoku Kasprowego Wierchu.

Jednym z nierozerwalnych ubocznych skutków obecności człowieka na terenie TPN jest powstawanie odpadów. W parku narodowym śmieci są pozostawiane przez turystów zarówno w wyznaczonych do tego miejscach, jak i przy schroniskach, na szlakach lub w ich pobliżu. Ze względów estetycznych - i przede wszystkim dla bezpieczeństwa zwierząt oraz ludzi - odpady muszą być systematycznie zbierane i usuwane $z$ terenu parku. Wydobywająca się z nich woń może przyciągnąć zwierzęta na szlak turystyczny, co z kolei stwarza bezpośrednie zagrożenie życia dla osób przebywających w tym miejscu. Ponieważ główną rolą parku narodowego jest ochrona przyrody, ingerencja człowieka $w$ jego krajobraz musi być bardzo ograniczona. $Z$ tego powodu podstawowa infrastruktura dotycząca gospodarowania odpadami - kosze i toalety - występuje $\mathrm{w}$ parkach narodowych tylko $\mathrm{w}$ nielicznych miejscach, głównie związanych z obsługą ruchu turystycznego (schroniska górskie, stacje narciarskie, wyznaczone wejścia na teren parku). W Tatrzańskim Parku Narodowym jest trochę inaczej. Wzdłuż wytyczonych szlaków, których łączna długość wynosi 275 km, brakuje koszy na śmieci. Wyjątek stanowi kilka tras utworzonych po to, aby kanalizowały masowy ruch turystyczny. Przy tych szlakach przygotowane są miejsca z toaletami i koszami na odpady podlegające stałemu nadzorowi. Celem tak zorganizowanego systemu gospodarowania odpadami w TPN jest spowodowanie, aby turysta był osobiście odpowiedzialny za swoje śmieci i nie pozostawiał ich na terenie parku, lecz wynosił je we własnym plecaku. Niestety odpady stale pojawiają się na szlakach oraz $\mathrm{w}$ innych miejscach parku (fot. 2). Skala jego zaśmiecenia jest szczególnie widoczna podczas podejmowanych akcji sprzątania przez wolontariuszy, co często bywa nagłaśniane w mediach ogólnopolskich. 


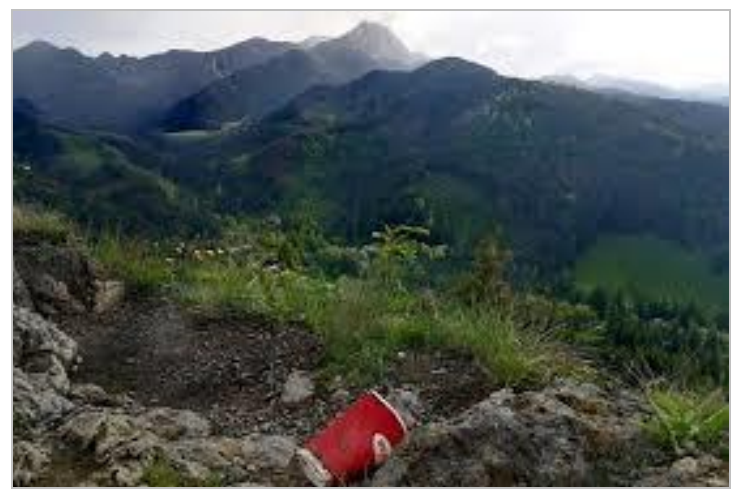

Fot. 2. Śmieci na Nosalu

Źródło: 300 metrów przestrzennych śmieci...

Problemem dla Tatr są tzw. amatorzy gór, nie zawsze odpowiednio przygotowani do warunków, jakie panują na tym terenie. Było i wciąż jest wiele przypadków nieprzemyślanych wycieczek górskich. W mediach głośno było na temat pewnego turysty, po tym jak poślizgnął się na szlaku wymagającym użycia raków i czekana, których nie posiadał. Do spontanicznej wędrówki zachęciła go słoneczna pogoda panująca u podnóża Tatr. Inna turystka wybrała się w zimowy dzień na Kasprowy Wierch w dżinsach, cienkich rękawiczkach i zwykłych miejskich butach. Termometr na szczycie wskazywał wówczas $-21^{\circ} \mathrm{C}$. Jej ubiór nie był odpowiedni do takiej wycieczki ( $W$ dżinsach i miejskich butach...).

Zdaniem autorki Tatrzański Park Narodowy jest jednym z najpiękniejszych parków w Polsce. Niestety, jego użytkowanie przez turystów, często bezmyślne i nieodpowiedzialne, powoduje niszczenie tego, co natura tworzyła przez kilkaset milionów lat. Obecna moda na podróżowanie i konsumpcjonizm sprawia, że zapominamy o tym, co jest naprawdę ważne dla ludzi $\mathrm{w}$ kontaktach $\mathrm{z}$ naturą. $\mathrm{W}$ przyrodzie panuje harmonia, piękno, moc, tajemniczość, symptomy „raju”. Kontakt fizyczny i psychiczny z naturą może pomóc człowiekowi niekiedy bardziej niż ktoś bliski. Ludzie nie zawsze to dostrzegają i nie umieją z tego korzystać, raczej skupiając się na pochwaleniu się znajomym bądź w Internecie kolejnym zdobytym szczytem lub wjazdem na Kasprowy Wierch kolejką liniową. Nie potrafią docenić obecności zieleni dookoła lub oddychania czystym powietrzem, napawać się ciszą czy widokiem malowniczego krajobrazu górskiego. Bywa, że z rozmysłem niszczą roślinność, zaśmiecają środowisko i hałasem niepokoją zwierzęta. 
Tatry stały się tak popularnym miejscem, że liczba turystów przytłacza, nie pozwalając każdemu swobodnie nacieszyć się wszystkim, co go otacza. Bezmyślność turystów polega także na nieodpowiednim przygotowaniu i wyposażeniu do chodzenia po górach (np. niewłaściwe obuwie czy odzież), nieznajomości środowiska, w którym przebywają, a także braku wiedzy na temat zmienności warunków pogodowych w górach. Prawdziwego turystę górskiego można poznać po jego wyglądzie i zachowaniu - powinien to być człowiek spokojny, uważny, cichy, przestrzegający przepisów związanych z przebywaniem na terenach chronionych, szanujący przyrodę, ale także uprzejmy wobec współużytkowników szlaków (wymiana powitań z napotykanymi osobami, niesienie pomocy lub służenie radą).

Zdaniem autorki opłaty za wejście do Tatrzańskiego Parku Narodowego powinny zostać znacznie zwiększone. $W$ ten sposób można by wpłynąć na zmniejszenie ruchu turystycznego na jego obszarze, ale przede wszystkim zwiększyć budżet TPN na cele ochrony tego miejsca, w tym na położenie nacisku na uświadamianie tzw. przypadkowym turystom konsekwencji dla nich i dla potomnych, wynikających z nieodpowiedniego korzystania z walorów przyrody. Wszyscy powinniśmy bowiem szanować Ziemię, na której żyjemy, aby następne pokolenia mogły tak jak my dzisiaj cieszyć się skarbami natury.

\section{Bibliografia}

300 metrów sześciennych śmieci w Tatrach. Pobrane z: https://www.zakopane.info/wiadomosci, 300-metrow-szesciennych-smieci-w-tatrach,wia5-3273-422.html (28.11.2018).

Chrobak, A., Zwijacz-Kozica, T. (red.) (2015). Przyroda Tatrzańskiego Parku Narodowego a człowiek. Monografia konferencyjna. Nauka Tatrom. T. 3: Człowiek $i$ środowisko. Zakopane: Tatrzański Park Narodowy. Polskie Towarzystwo Przyjaciół Nauk o Ziemi - Oddział Krakowski. Pobrane z: http://tpn.pl/upload/filemanager/sekcja3_low-res.pdf (28.11.2018).

Gleby TPN. Pobrane z: http://www.tpn.pl/files/news/editor/files/Foldery/gleby_TPN.pdf (28.11.2018).

Krzan, Z. (2006). Tatrzański Park Narodowy na tle innych górskich terenów chronionych. T. 3: Człowiek i środowisko. Zakopane: Wyd. nakł. Tatrzańskiego Parku Narodowego.

W dżinsach i miejskich butach poszła na Kasprowy Wierch. Interweniować musiat TOPR. Pobrane z: http://krakow.wyborcza.pl/krakow/7,44425,23076866,w-dzinsach-i-miejskichbutach-poszla-na-kasprowy-wierch-interweniowac.html (28.11.2018). 